\title{
New insights into the effect of amorolfine nail lacquer
}

\author{
C. Flagothier, C. Piérard-Franchimont and G. E. Piérard
}

Department of Dermatopathology, University Hospital of Liège, Liège, Belgium

Summary

Key words: amorolfine, antifungal, fungus, onychomycosis, spore.

\section{Introduction}

During the last 2 decades, the efficacy of treating onychomycoses has been considerably improved by the introduction of new generations of potent antifungals. In general, antifungal therapy has taken a quantum leap forward in response to the physicians' need to control the ever growing number of diagnosed mycotic infections. At the same time, the existence of several different treatment plans with drugs that differ in many of their characteristics has led to disagreements in formulating indications for their use and assessing their clinical efficacy. Opinions have been expressed attempting to link the overall efficacy of the drugs with its pharmacokinetic and pharmacodynamic characteristics. Furthermore, these parameters have themselves sometimes been put forward as significant advantages or disadvantages for one or another of the antifungals compared with others.

Correspondence: Professor G. E. Pierard, Department of Dermatopathology, CHU Sart Tilman, B-4000 Liège, Belgium.

Tel.: +32 4 3662408. Fax: +3243662976.

E-mail: gerald.pierard@ulg.ac.be

Accepted for publication 29 November 2004
Topical treatments are often considered to be less efficacious than current oral treatments. However, some topical formulations may provide effects that cannot be achieved by other treatments. In discussing the treatment of onychomycosis, it should not be forgotten that all systemic antifungals exert only fungistatic activity in clinical conditions. Radical elimination of the causal microorganism from the nail does not occur frequently. ${ }^{1,} 2$ In fact, if antifungals were to exert fungicidal activity, completely destroying fungi in the nail, the duration of treatment of toenail and fingernail onychomycoses would be identical. However, this does not happen in practice, and treatment plans for toenail onychomycosis are always more prolonged compared with those for fingernail onychomycosis. The overall difference in duration between these treatment plans corresponds overall to the difference in the complete regrowth rate of nail plates on the feet and hands.

\section{Antifungal activity of amorolfine}

Amorolfine is a potent antifungal drug exhibiting a large spectrum of in vitro activity. ${ }^{3,4}$ However, in the field of onychomycosis, data gained by conventional in vitro testing ${ }^{5}$ cannot be taken at face value and extrapolated to the in vivo situation. ${ }^{6}$ This is probably 
due to drug interference with natural compounds that can influence fungal growth. In addition, contrasting with the in vitro testing in culture medium, fungi in onychomycosis utilize the nail as their sole nutrition source. Therefore they have to change their metabolism, activating for instance the secretion of keratinases. ${ }^{7}$ As a result of the specific nail environment and fungal condition, the activity of antifungals may be considerably decreased in nails compared with standard in vitro testing procedures. ${ }^{8}$

The pharmacokinetic properties of amorolfine in nails suggest a good penetration deep into the subungual compartment. 4, 9, 10 Therapeutic results in onychomycosis have been reported on several occasions. ${ }^{11-15}$ The patient's ability to use the treatment correctly and his/ her compliance should not be overlooked in selecting the treatment.

\section{Fungal adherence and invasiveness}

In addition to the antifungal and nail characteristics, the taxonomic nature and life cycle of the offending fungi are important. Numerous types of fungal propagules (spores) are present in the environment, some of which can be responsible for onychomycosis. The first step in the complex pathogenic path of onychomycosis consists of propagule adherence to the surface of the nail or the surrounding skin. Invasion may follow, leading to hyphae and conidia formation, and subsequent dispersal of propagules, thus closing the pathogenic circle.

Intact skin and nail usually prevent the penetration of most pathogenic fungi. Contact with skin scales harboring the fungus is commonly an essential step in the development of superficial fungal infections. Indeed, the adherence of tiny infected scales or fungal propagules is the primary mechanism of fungal transmission. Discrete abrasion of the stratum corneum and presence of soft keratin accumulation under the distal part or the lateral margins of the nail plate are friendly niches for adherence of fungal propagules. Occlusion also helps these infectious cells to cling to the cornified structures. As fungal cells can survive for up to 2 years in a viable state in scales, nail fragments and hair, the original contact with an infective fungus is therefore indirect in many instances.

Most experimental fungal invasions of the stratum corneum rely on abrasion of the skin surface or occlusion before dermatophytes can be induced to establish themselves effectively as pathogens. However, the fungal inocula must usually be far heavier than is usually experienced in an in vivo situation. In addition, these studies do not take into account the facilitating or inhibitory effects of endogenous molecules and products from other saprophytic microorganisms already colonizing the skin. Furthermore, the importance of carbon dioxide $\left(\mathrm{CO}_{2}\right)$ cannot be neglected due to its essential role in both the formation of fungal propagules and also the germination of the arthroconidia, resulting in hyphal penetration of the cornified structures. High $\mathrm{CO}_{2}$ concentrations facilitate subsequent formation of arthroconidia. In contrast, onychocytes and corneocytes may contain certain soluble factors that induce arthroconidia germination. Amino acids from human corneocytes are important in this process. Some endogenous antimicrobial peptides exert the apposite effect and act in the scope of innate immunity. ${ }^{16-21}$

\section{The conidia-hyphae-conidia loop}

If an infected skin scale is released in a swimming pool or shower cubicle, attachment of the fungus to corneocytes allows its activation. The state of dormancy is broken due to increased moisture levels that lead to the initiation of germination and penetration of the cornified structures. Along the invasive fungal path, germination after propagule attachment must be rapid, otherwise the fungus is expelled by continuous desquamation, nail growth and regular body cleansing. During the invasive hyphal phase, arthrocondiia are eventually formed again, through asexual reproduction. $1,2,22-24$ This process involves the division of hyphae into strings of short segments separated by double septa. This situation represents the resting state of an otherwise filamentous fungus. In this state of dormancy arthroconidia can survive for very long periods of time, protected to a large extent from harsh environmental conditions. These cells are also less sensitive to the vast majority of antifungals. ${ }^{2}$

At this stage, the fungal life is already approaching full circle. Indeed, the pathogenic loop begins with the formation of hyphae that, in turn, disarticulate into arthroconidia, and concludes with the release of infectious propagules again. This cycle lends itself to elegant studies with antimycotics, using the corneofungimetry bioassay performed on small strips of stratum corneum. ${ }^{6,25-28}$ This model permits the study of adherence, germination and penetration of fungi in the human stratum corneum. The effect of topical or oral antifungals can be established as well. ${ }^{6,25,27-29}$

\section{Amorolfine nail lacquer and fungal adherence}

The ability of fungi to attach themselves to body surfaces is the first incident in the chain of events that 
eventually results in the requirement for antimycotic treatment. Identifying the organism and understanding the successive steps of its pathogenic path are important to improve therapeutic outcome.

We performed an in vitro study using non-infected big toenails obtained at autopsy. Samples coated or uncoated with amorolfine nail lacquer were placed in humidified soil for 4 weeks. Samples were then washed, immersed in Tween 40 and prepared for histological examination as previously described. ${ }^{22,23,} 30$ Controluntreated nails showed fungal invasion in 16 of 18 $(88.9 \%)$ cases. In contrast, only three of $18(16.7 \%)$ of the amorolfine-treated samples harbored fungal hyphae. These findings suggest that nail adhesion and growth of keratinophylic fungi present in soil are largely inhibited by medicated formulation. The nail lacquer may have inhibited fungal adhesion, and amorolfine would have probably abated incipient hyphae production.

\section{Waking fungal conidia from dormancy}

The presence of resting conidia inside the nail plate represents a potent reservoir little affected by antifungals. ${ }^{2}$ Growth of hyphae and recurrence of onychomycosis may occur from these conidia when treatment is stopped. ${ }^{22}$ Therefore, targeting this drug-resistant population of cells is a key feature in onychomycosis management. This objective is conceivable through the use of nail lacquer formualtions, which may act to break this state of dormancy during treatment by reducing transonychial water loss (TOWL). The normal TOWL ranges between 10 and $20 \mathrm{~g} \mathrm{~m}^{-2} \mathrm{~h}^{-1}$, and is significantly lowered in onychomycosis. ${ }^{31}$ We found that the level of TOWL was further abated after application of amorolfine nail lacquer. This results from the semiocclusive property of the formulation that may retain moisture in the nail plate facilitating fungal germination. The induction would result in the emergence of fungal hyphae susceptible to the antifungal activity of amorolfine. Thus, amorolfine formulation is well suited for eradicating resistant arthroconidia.

Another way to circumvent this fungal life process consists in luring the dormant fungus by boosting its growth while on antifungal treatment. The boosted antifungal topical treatment modality showed success using amorolfine nail lacquer. ${ }^{32}$ This procedure is safe when the antifungal agent has a broad spectrum of activity and when the boosting period is limited to 1 week. ${ }^{32}$ As natural host defenses are not impaired by treatment, the risk of systemic spread of infection is no higher than that observed in untreated patients with onychomycosis.

\section{Conclusion}

It is a problem familiar for all dermatologists that a number of cases of onychomycoses can be alleviated or improved but not cured. There is ample evidence that some broad-spectrum antifungals including amorolfine are effective in vitro against a wide range of fungi responsible for onychomycoses. However, the clinical effect in treating onychomycosis is less impressive than expected. The reasons are multiple, depending both on the biology of the fungus and the nature of the nail containing a mixture of fungal growth-promoting and fungal growth-inhibiting factors. As a rule, the resulting overall balance between antifungal drug efficacy and the onychomycosis condition is negative. Amorolfine does not escape this drawback. However, topical nail laquer formulation has some advantages over oral antifungals. It limits the adhesion of fungal propagules on and underneath the nail plate, thus preventing reinfection in its initial step. It also helps in hydrating the nail plate by semi-occlusion, thus limiting the formation and persistence of drug-resistant fungal spores.

\section{References}

1 Arrese JE, Piérard-Franchimont C, Piérard GE. Facing up to the diagnostic uncertainty and management of onychomycoses. Int J Dermatol 1999; 38: S1-6.

2 Arrese JE, Piérard-Franchimont C, Piérard GE. A plea to bridge the gap between antifungals and the management of onychomycosis. Am J Clin Dermatol 2001; 2: 281-4.

3 Polak AM. Preclinical date and mode of action of amorolfine. Clin Exp Dermatol 1992; 1: 8-12.

4 Polak AM, Dixon DM. Antifungal activity of amorolfine in vitro and in vivo. In: Fromtling R (ed.), Recent Trends in the Discovery, Development and Evaluation of Antifungal Agents. Barcelona: JR Prous Science Publications, 1987: 555-73.

5 Favre B, Hofbauer B, Hildering KS, Ryder NS. Comparison of in vitro activities of 17 antifungal drugs against a panel of 20 dermatophytes by using a microdilution assay. J Clin Microbiol 2003; 41: 4817-9.

6 Arrese JE, De Doncker P, Odds F, Piérard GE. Reduction in the growth of non-dermatophyte molds by itracoanzole: evaluation by the corneofungimetry bioassay. Mycoses 1998; 41: 461-5.

7 Takasuka T. Amino acid- or protein-dependent growth of Trichophyton metagrophytes and Trichophyton rubrum. FEMS Immunol Med Mic 2000; 29: 241-5.

8 Osborne CS, Leitner I, Favre B, Ryder NS. Antifungal drug response in a in vitro model of dermatophyte nail infection. Med Mycol 2004; 42: 159-63.

9 Mensing H, Polak-Wyss A, Splanemann V. Determination of the subungual antifungal activity of amorolfine after 1 month's treatment in patients with onychomycosis: 
comparison of two nail lacquer formulations. Clin Exp Dermatol 1992; 17: S29-32.

10 Polak A. Kinetics of amorolfine in human nails. Mycoses 1993; 36: 101-3.

11 Lauharanta J. Comparative efficacy and safety of amorolfine nail lacquer $2 \%$ versus $5 \%$ once weekly. Clin Exp Dermatol 1992; 1: 41-43.

12 Reinel D, Clarke C. Comparative efficacy and safety of amorolfine nail lacquer 5\% in onychoycosis, once weekly versus twice-weekly. Clin Exp Dermatol 1992; 1: 44-49.

13 Zaug M, Bergstrasser M. Amorolfine in the treatment of onychomycoses and dermatomycoses (an overview). Clin Exp Dermatol 1992; 18: 61-70.

14 Zaug M. Amorolfine nail lacquer: clinical experience in onychomycosis. J Eur Acad Dermatol Venereol 1995; 4: S23.

15 Maleszka R, Ratajczak V, Turek-Krainska K. The use of amorolfine in the treatment of dermatophyte onychomycosis. Prz Dermatol 2002; 89: 493.

16 Nizet V, Ohtake T, Lauth X et al. Innate antimicrobial peptide protects the skin from invasive bacterial infection. Nature 2001; 414: 454-7.

17 Gallo RL, Murakami M, Ohtake T, Zaiou M. Biology and clinical relevance of naturally occurring antimicrobial peptides. J Allergy Clin Immunol 2002; 110: 823-31.

18 Janeway Jr CA, Medzhitov R. Innate immune recognition. Annu Rev Immunol 2002; 20: 197-216.

19 Zasloff M. Antimicrobial peptides of multicellular organisms. Nature 2002; 415: 389-95.

20 Dorschner RA, Lopez-Garcia B, Massie J, Kim C, Gallo RL. Innate immune defense of the nail unit by antimicrobial peptides. J Am Acad Dermatol 2004; 50: 343-8.

21 Schröder JM. Peptides epithéliaux antimicrobiens. Molécules de défenses constitutionnelles locales. Ann Dermatol Venereol 2004; 31: 411-6.

22 Arrese JE, Piérard GE. Treatment failures and relapses in onychomycosis: a stubborn clinical problem. Dermatology 2003; 207: 255-60.
23 Arrese JE, Quatresooz P, Piérard-Franchimont C, Piérard GE. Histomycologie unguéale. Ann Dermatol Venereol 2003; 130: 1254-9.

24 Piérard GE, Arrese JE, Quatresooz P. Histomycologie de la biodiversité des onychomycoses. In: Baran R, Piérard GE (eds), Onychomycoses. Paris: Publ. Abrégés Masson, 2004: 91-104.

25 Rurangirwa A, Piérard-Franchimont C, Piérard GE. Culture of fungi on cyanoacrylate skin surface strippings. A quantitative bioassay for evaluating antifungal drugs. Clin Exp Dermatol 1989; 14: 425-8.

26 Aljabre SH, Richardson MD, Scott EM, Shankland GS. Germination of Trichophyton mentagrophytes on human stratum corneum in vitro. J Med Vet Mycol 1992; 30: 145-52.

27 Piérard GE, Arrese JE, De Doncker P. Antifungal activity of itraconazole and terbinafine in human stratum corneum: a comparative study. J Am Acad Dermatol 1995; 32: 429-35.

28 Arrese JE, Fogouang L, Piérard-Franchimont C, Piérard GE. Euclidean and ractal computer-assisted corneofungimetry. A comparison of $2 \%$ ketoconazole and $1 \%$ terbinafine topical formulations. Dermatology 2002; 204: 222-7.

29 Piérard GE, Arrese JE, Piérard-Franchimont C. Itraconazole corneofungimetry bioassay on Malassezia species. Mycoses 2004; 47: 418-21.

30 Piérard GE, Arrese JE, Pierre S et al. Diagnostic microscopique des onychomycoses. Ann Dermatol Venerol 1994; 121: 25-29.

31 Kronauer C, Gfesser M, Ring J, Abeck D. Transonychial water loss in healthy and diseased nails. Acta Dermatol Venereol 2001; 81: 175-7.

32 Piérard GE, Piérard-Franchimont C, Arrese JE. The boosted antifungal topical treatment (BATT) for onychomycosis. Med Mycol 2000; 38: 391-2. 